\title{
Time-counting expressions as aspectual complex numerals*
}

\author{
Expressões de contagem de tempo como \\ numerais complexos aspectuais
}

\author{
Anna Maria Di Sciullo* \\ Manuel Español-Echevarría
}

\begin{abstract}
We compare the syntactic and semantic properties of time-counting expressions to those of better studied counting systems, such as complex cardinal numerals (KAYNE，2005，2016; IONIN; MATUSHANSKY， 2006; STAVROU; TERZI, 2008; DI SCIULLO, 2012, 2015, inter alia). From a typological point of view, we will focus on Romance languages. We argue that time-counting expressions, as opposed to complex numerical expressions, may have specific aspectual properties. We observe first that time-counting expressions involve a "salient" reference time, henceforth SRT, on the basis of Italian and Spanish. We argue that this salient reference hour-time may denote either a timepoint or a time-interval. The time-point interpretation of the SRT gives rise to telic construals in some cases. The lack of SRT makes number phrases not interpretable as time denoting expressions. The telic construals usually involve locative or goal prepositions, such as a "to" in Italian, para "for" in Portuguese or to in English. On the other hand, time-interval interpretations of SRT are typical of time-counting expressions involving pseudopartitives in languages like Catalan. In these cases, the reference-time is not viewed as the endpoint of a telic interval. We also discuss telic cases similar to the pseudo-partitive ones in that they involve [quarter + minutes] constituents, but involving aspectual prepositional projections. We analyze timecounting expressions in terms of extended prepositional projections including RelView categories, discussed in Cinque and Rizzi (2010) for the syntax-semantics of locative/directional prepositions, in order to formalize the spatial location of time. By doing so, we propose a unified account for the variety of Romance languages time-counting expressions.
\end{abstract}

Keywords: time-counting expressions, preposition extended projections, relative view

\footnotetext{
* We thank the audience at the XI Workshop of Formal Linguistics, UFPR, Curitiba, Brazil, for their comments on a previous version of this paper. This work was supported in part by funding from the Fonds de recherche du Quebec for the Research on Dynamic Interfaces, grant number 137253. www.interfaceasymmetry.uqam.ca; www.biolinguistics.uqam.ca

** University of Quebec in Montreal and New York University

${ }^{\star \star \star}$ Laval University
} 
Comparamos as propriedades sintáticas e semânticas das expressões de contagem de tempo com as dos sistemas de contagem mais bem estudados, como os números cardinais complexos (KAYNE, 2005, 2016; IONIN; MATUSHANSKY, 2006; STAVROU; TERZI, 2008; DI SCIULLO, 2012, 2015, inter alia). Do ponto de vista tipológico, focaremos nas Línguas Românicas. Argumentamos que as expressões de contagem de tempo, ao contrário de expressões numéricas complexas, podem ter propriedades aspectuais específicas. Observamos primeiro que as expressões de contagem de tempo envolvem um tempo de referência "saliente", doravante SRT, com base no italiano e no espanhol. Argumentamos que esta hora-tempo de referência saliente pode indicar um ponto de tempo ou um intervalo de tempo. Uma interpretação de um ponto de tempo do SRT dá lugar a interpretações télicas em alguns casos. A ausência de SRT torna sintagmas numéricos não interpretáveis como expressões denotadoras de tempo. As interpretações télicas geralmente envolvem preposições locativas ou alvo, como a "a" em italiano, para em português ou to "para" em inglês. Por outro lado, as interpretações de intervalo de tempo de SRT são típicas das expressões de contagem de tempo envolvendo pseudo-partitivos em linguagens como o catalão. Nesses casos, o tempo de referência não é visto como o ponto final de um intervalo télico. Também discutimos casos télicos semelhantes aos pseudopartitivos, na medida em que envolvem constituintes [quarto + minutos], mas também projeções preposicionais aspectuais. Analisamos as expressões de contagem de tempo em termos de projeções preposicionais estendidas, incluindo categorias RelView, discutidas em Cinque and Rizzi (2010) para sintaxesemântica de preposições locativas / direcionais, a fim de formalizar a localização espacial do tempo. Ao fazê-lo, propomos uma conta unificada para a variedade de expressões de contagem de tempo das Línguas Românicas.

Palavras-chave: expressões de contagem de tempo, preposição de projeções prolongadas, categoria RelView. 
A. M. Di

SCIULLO \&

M. ESPAÑOL-

ECHEVARRÍA

Time-counting

expressions as aspectual complex numerals

\section{Purpose}

$\mathrm{W}$

e explore the formal and the aspectual properties of time-counting expressions in Romance languages. Considering expressions such as the ones in (1) and (2), we raise the following questions:

What is the role of prepositions in these expressions and what do time-counting expressions tell us about the properties of the Language Faculty?

(1)

un quarto alle cinque (It.)

a quarter to the five

"a quarter to five"

(2)

dos quarts i cinc de nou (Ca.)

two quarters and five of nine

"eight thirty-five"

It is well known that prepositional structure (PP) may delimit events in the verbal projections (TENNY, 1987; DI SCIULLO; TENNY, 1997; DI SCIULLO, 1997, 2005; TRAVIS, 2000; RAMCHAND, 2008; GARCIAPADRO, 2015, inter alia). The delimiting properties of PPs in DPs is however open to further inquiry. We develop the hypothesis formulated in Di Sciullo (2016) according to which time-counting expressions are part of the extended nominal projection, including numeral cardinals (Numcard), see (3) from

Revista Letras, Curitiba, UFPR, n. 96 , pp.377-397, jul./dez. 2017. ISSN 2236-0999 (versão eletrônica) 
Cinque (2005). They provide a domain in which the operations of the Language Faculty relate number, time and space via prepositions.

$$
\begin{aligned}
& {[\text { Quniv ... [Dem ... [Numord ... [RC ... [Numcard ... }} \\
& {[\mathrm{Cl} \ldots[\text { A ... NP]]]]]] }]}
\end{aligned}
$$

(Cinque 2005)

According to the Strong Minimalist Thesis (CHOMSKY 2001, et seq.), language is an optimal solution to interface conditions, in that language is an optimal way to link sound and meaning. There is a significant asymmetry between the conceptual intentional (C-I) interface, the system of thought, and the sensorimotor $(\mathrm{SM})$ interface externalizing the system of thought, with the first having primacy. Interface asymmetries arise with unpronounced constituents. The internal syntax of time-counting expressions analyzed in Kayne (2005, 2016) includes unpronounced nominal expressions, such as HOURS and YEARS. We focus on the derivation of time-counting expressions as cases of interface asymmetries including unpronounced prepositional constituents.

We assume that prepositions project additional functional structure (VAN RIEMSDIJK, 1990; JACKENDOFF, 1983; KOOPMAN, 2010; DEN DIKKEN, 2010; TORTORA, 2008; KOOPMAN, 2000; TERZI, 2010; CINQUE; RIZZI, 2010; SVENONIUS, 2010). We provide arguments to the effect that, in some cases, the prepositional structure delimits time-counting expressions, whereas in other cases it does not support telic construals. The evidence comes from temporal boundaries, time span vs. durative modification, and point of view. We propose a unified derivation of time-counting expressions and variation between Romance languages. We draw consequences for the understanding of aspect in time-counting expressions, given the ConceptualIntentional (CI) and Sensorimotor (SM) interface asymmetries.

Firstly, we discuss some properties of cardinal numerals and timecounting expressions and the derivation of cardinal numbers, such as vingtet-un (Fr.) (twenty and one) 'twenty-one' and time-counting expressions, such as le due e mezzo (It.) (the two and half) 'two thirty'. We argue that cardinal numerals merge with additive and multiplicative morphology, e.g. one hundred (and) one. This morphology is silent in some cases, e.g. venti due (It.) 'twenty-two', due cento (It.) 'two hundred"; however it is nevertheless legible at the CI interface. Secondly, we argue that sometimes silent conjunctions and prepositions are part of the derivation of cardinal numbers and time-counting expressions. These expressions include unpronounced nouns, such as HOUR and YEAR (KAYNE 2003, 2006, 2015), and sometimes silent prepositional structure parting, orienting, and delimiting time in abstract space (DI SCIULLO, 2016). Interestingly, the prepositional structure may in some cases have delimiting properties, e.g. un quarto *(alle due) (It.) 'a quarter *(to two)', as 
A. M. Di

SCIULLO \&

M. ESPAÑOL-

ECHEVARRÍA

Time-counting

expressions as aspectual complex numerals

well as a Relative View property (CINQUE; RIZZI, 2010, et seq.), compare the preceding example to the following le due meno un quarto (It.) (the two minus one quarter) 'a quarter to two'. However, pseudo-partitive morphology does not have a delimiting effect in cases such as the following from Catalan, e.g. un quart i cinc de nou (a quarter and five of nine) 'twenty past eight'. Thirdly, we rely on Cinque and Rizzi's (2010) extended projection of prepositions in order to identify the spatial location of time with time denoting expressions. We derive the differences between Romance languages regarding the variation in the form and interpretation of time denoting expressions. In the last section, we draw the consequences of our analysis for the understanding of how the operations of the Language Faculty relate number, time and space.

\section{Cardinal numerals}

\subsection{The structure of cardinal numerals}

In this section, we present an overview of our assumptions on the structure of cardinal numerals as well as the aspects of their syntax-semantic properties they share with time-counting expressions.

Cardinal numerals are generally assumed to occupy the Specifier of numeral phrase (NumP), (4). This is the case in Ionin and Matushansky (2006) analysis, based on X-bar structure and type theoretical semantics, as well as in Stavrou and Terzi (2008).1

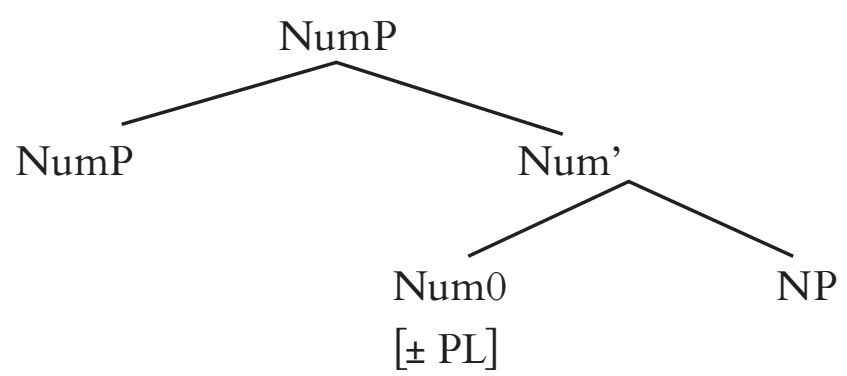

For Ionin and Matushansky (2006), additive structures, such as twenty two, are analyzed as conjunctions; whereas multiplicative structures, such as two hundred, are analyzed as complementation structures. Di Sciullo (2012) proposes that complex numerals include a functional head that can be pronounced in some cases, as in (5). The functional head has both valued and unvalued features. The unvalued $(\mathrm{u})$ features [uNum] are checked and eliminated. In additive structures, 1 Several other analyses have been proposed for the internal structure of complex cardinal numerals, including a flat structure (Zabbal 2005). We will assume that the internal structure of these expressions is asymmetrical, and thus not reduced to a sisterhood relation. See Di Sciullo

Revista Letras, (2015) for discussion.

Curitiba, UFPR, n. 96 , pp.377-397, jul./dez. 2017. ISSN 2236-0999 (versão eletrônica) 
the valued $[\mathrm{ADD}]$ feature is interpreted as a non-Boolean conjunction operator and thus has a group reading.

(5)<smiles>N#CC(N)CN</smiles>

The operator feature $[\mathrm{ADD}]$ is spelled out as the coordination conjunct e "and" in Italian cardinal numerals, as in cento e uno "hundred and one", as well as in time-counting expression, as in Italian le due e cinque (the two and five) "five past two". In cardinal numerals, the non-Boolean interpretation (group reading) of $[\mathrm{ADD}]$ is part of their semantic interpretation whether it is pronounced or remains silent.2 Thus, following Di Sciullo (2012, 2015), we assume that unpronounced functional heads are part of the structure of cardinal numerals.

Furthermore, we assume that the subtractive operator [SUB] is also an operator feature in time counting expressions and it is spelled out as a preposition de "from" in Latin cardinal numerals, as in duo de viginti (two from twenty) "eighteen", and meno "minus" in Italian, as in le due meno cinque (the two 382 minus five) "five to two".

We thus take $[\mathrm{ADD}]$ and $[\mathrm{SUB}]$ to be independently motivated and to be part of the set of interpretable operator features in cardinal numerals.

2 While languages vary according to the pronunciation or silence of [ADD], e.g. ventuno (It.) vs. vingt-et-un (Fr.) "twenty one", the group reading for additive cardinal numerals is preserved when the coordinating conjunction is not pronounced, compare (ii) and (iv) below:

i. $\quad$ Il y a vingt-et-un livres en tout sur cette étagère. (Fr.) it there has twenty and one books in all on this shelf "There are twenty one books in all on this shelf."

ii. $\quad$ \#Il y a vingt livres en tout et un livre en tout sur cette étagère. it there has twenty books in all and one book in all on this shelf "There are twenty books in all and one book in all on this shelf."

iii. John read twenty-one books altogether.

iv. \#John read twenty books altogether and one book altogether. 
A. M. Di

SCIULlo \&

M. ESPAÑOL-

ECHEVARRÍA

Time-counting

expressions as aspectual complex numerals

\subsection{The position of the digit with respect to the base}

There is variation in the position of the digit with respect to the base in cardinal numeral numbers. For example in Latin, inverse ordering of the base with respect to the digit is observed in additive cardinal structures, as the examples in (6) illustrate.

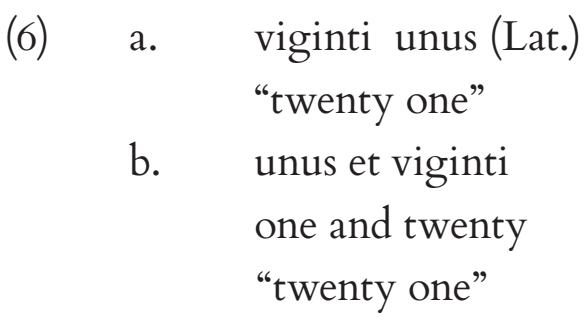

The derivations for the different orderings of the constituents of cardinal numerals can proceed as follows. Two numerals are first merged. A functional head is externally merged to the result. One or the other of the two numerals is internally merged to the functional head, (7).

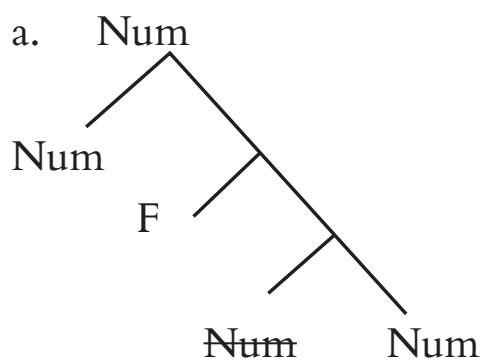

b.

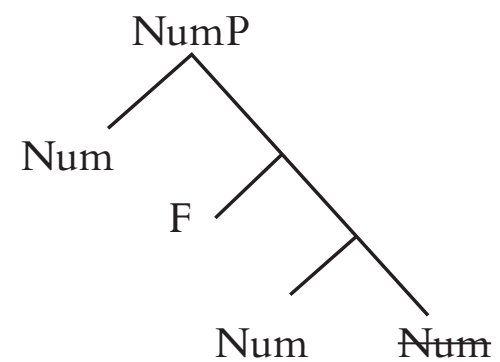

The different linearization of the parts of cardinal numerals follow from the computational procedure of the Language Faculty, where a single operation derives structure building (External Merge) and displacement (Internal Merge) (see Chomsky, 2000 et seq.). See Di Sciullo (2015) for further discussion.

\subsection{Perspectives}

The fact that two structures may be used to refer to the same cardinal number suggests that cardinal numerals can be expressed in different perspectives. This is the case in Latin for example, as we illustrate in (8). These examples show that there is variation in the order of the digit with respect to the base near the tenths. They show further that the preposition de "from" must be pronounced in cases where the digit precedes the base.

$\begin{array}{lll}\text { (8) a. } \quad \begin{array}{l}\text { octo decim (Lat.) } \\ \text { eight ten } \\ \text { "eighteen" }\end{array} & \begin{array}{l}\text { novem decim (Lat.) } \\ \text { nine ten } \\ \text { "nineteen" }\end{array}\end{array}$

Revista Letras,

Curitiba, UFPR, n. 96, pp.377-397, jul./dez. 2017. ISSN 2236-0999 (versão eletrônica) 

b. duo de viginti (Lat.) two (down) from twenty
d. un de viginti (Lat.)
"eighteen"
one (down) from twenty
"nineteen"

The directional preposition brings about a spatial orientation in the interpretation of cardinal numerals. In (8a) and (8c) the individuation of a given number is relative to the lower base, ten, whereas in $(8 b)$ and (8d), it is relative to the higher base, twenty, as represented in (9).
(9)
a.
$10 \ldots . . .8 .20$
b. $10 \ldots \ldots .2 .20$

We provide evidence that this is also the case for time-counting expressions in section 3 .

\subsection{Relative View}

We follow Di Sciullo (2016) and take that the derivation of cardinals includes projections of Relative View (RelView) in the extended functional projection for preposition, for example the one in (10) from Cinque and Rizzi (2010).

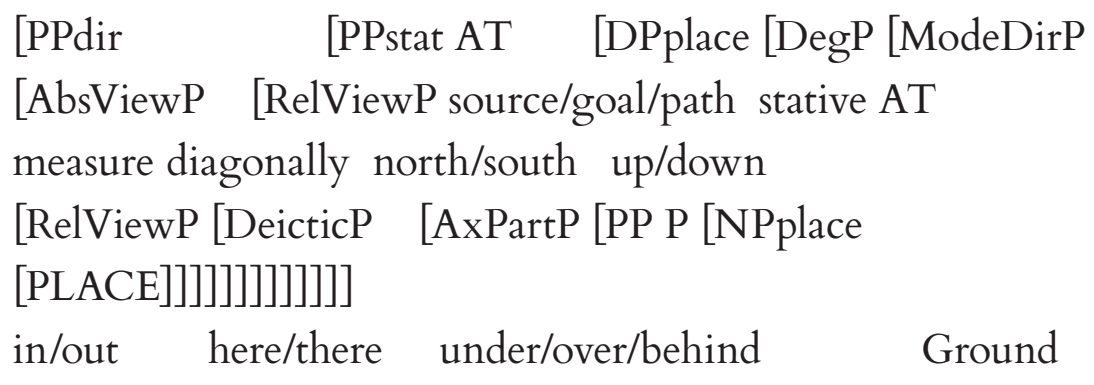

(CINQUE; RIZZI, 2010)

Assuming that cardinal numbers (used for counting) are points in the abstract space of Natural numbers as defined by Cantor (1914), Di Sciullo (2016) proposes to derive Latin duo de viginti "eigtheen" by the sequential displacement (Internal Merge) of duo from a lower position to the Specifier of the preposition "de", and subsequently to the Specifier of RelViewP, (11).

$$
\left[_{\text {RelViewP }} \text { duo DOWN }\left[_{\text {RelViewP }}[\text { duto }] \text { de }\left[_{\text {place }}[\text {-dur }] \text { viginti }\right]\right]\right]
$$

According to this analysis, the unpronounced preposition DOWN in (11) is part of the derivation of cardinal numerals and identifies the RelView of the digit with respect to the base. RelViewP contributes to individuate the spatial 
A. M. Di

SCIULlo \&

M. ESPAÑOL-

ECHEVARRÍA

Time-counting

expressions as aspectual complex numerals

location of a cardinal numeral in an abstract space from a given perspective. We show in section 3.3 that RelView is also part of the derivation of time-counting expressions.

\subsection{Section summary}

Summarizing so far, we take the internal structure of cardinal numerals to include conjunctions as well as prepositions and other functional elements in the extended functional projection of prepositions. We observed, on the basis of the properties of cardinal numerals in Romance languages, that there is language variation with respect to the linearization of the digit with respect to the base as well as in the pronunciation or silence of the conjunction and the preposition. The derivation of cardinal numerals follows from the recursive application of Merge in the extended nominal projection including RelViewP.

\section{Time-counting expressions}

In this section, we compare the syntactic and semantic properties of timecounting expressions to those of counting systems, such as cardinal numerals. We present arguments that prepositional structure may have delimiting properties in time-counting expressions. The evidence comes from overt and silent temporal delimiters, as well as time span vs. durative adverbial modification. We argue further that time-counting expressions include aspectual categories, including salient reference point and relative view. We distinguish telic and atelic time counting expressions and suggest a unified analysis of the variants in terms of extended functional projections for prepositions.

\subsection{Time-counting expressions and pronounced/silent constituents}

Time-counting expressions and cardinal numbers share properties, including pronounced functional categories, such as conjunctions and prepositions, as illustrated with the examples in (1) and (2) above, repeated here in (12) and (13).

$$
\begin{aligned}
& \text { un quarto alle cinque (It.) } \\
& \text { a quarter at-the five } \\
& \text { "a quarter to five" }
\end{aligned}
$$

Revista Letras,

Curitiba, UFPR, n. 96, pp.377-397, jul./dez. 2017. ISSN 2236-0999 (versão eletrônica) 
(13)

dos quarts i cinc de nou (Ca.) two quarters and five of nine "eight thirty-five"

Time-counting expressions also include silent constituents. Kayne $(2005,2006,2016)$ proposes to analyze time-counting expressions as including unpronounced nominals, including HOUR and O'CLOCK. In English, nouns, such as years, hour and time, can be silent, e.g. it is six: CLOCK TIMEi Fo [six HOUR] ti (KAYNE, 2005). Agreement relations provide evidence that this is also the case in morphologically rich languages such as Italian, (14).

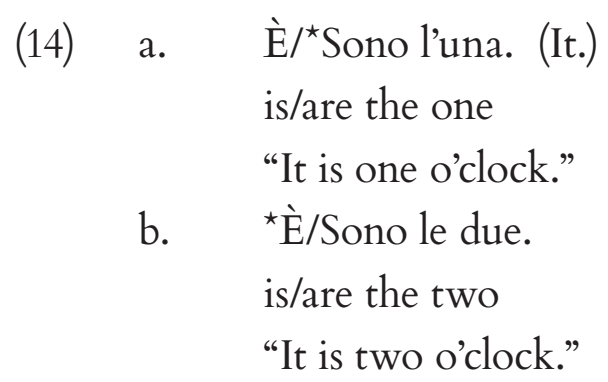

Locative and directional prepositions, sometimes unpronounced adverbial PPs are also part of time-counting expressions. The adverbial PPs provide a broader areal boundary to time-counting expressions, as evidenced by the contrast between $(15 \mathrm{a}, \mathrm{b})$ and $(15 \mathrm{c}, \mathrm{d})$ below.

(15) a. È l'una e mezza (di mattina). (It.)

is the one and half of morning

"It is half past one in the morning."

b. Sono le due meno un quarto (di pomeriggio).

are the two minus a quarter of morning

"It is a quarter to two in the morning."

c. \#Sono le due meno un quarto (di sera).

are the two minus a quarter of evening

"It is a quarter to two in the evening."

d. \#Sono le sette e mezza (di note).

are the seven and half of night

"It is seven thirty in the night."

Furthermore, hours can be divided in parts, such as quarters. Quarters are intervals that cannot be interpreted without a temporal endpoint brought about by PPs, (16a). Time span vs. durative PP modification, (16b), provide further support to the aspectual properties of time-counting expressions. 
A. M. Di

SCIULlo \&

M. ESPAÑOL-

ECHEVARRÍA

Time-counting

expressions as aspectual complex numerals

(16) a. È un quarto *alle due). (It.)

Is a quarter ${ }^{\star}$ (to two)

"It will be a quarter *(to two)."

b. Sarà un quarto alle due (tra pochi minuti/"*per pochi minuti). will be a quarter at two (in a few minutes $/{ }^{\star}$ for a few minutes) "It will be a quarter to two (in a few minutes $/{ }^{\star}$ for a few minutes)."

Prepositional constituents, be they pronounced or silent, contribute to delimit time-counting expressions in abstract space.

\subsection{Time-counting expressions and Salient Reference Time (SRT)}

Time-counting expressions of the sort we are considering here minimally involve a DP denoting the hour. In principle, given the availability of additive and subtractive operator features in a given language, see section 1.3 above, reference to a concrete time-point could be made either with respect to the preceding or to the following hour, as shown in the Italian examples in (17a) $-(18 \mathrm{a})$ :

(17) a. le tre e cinque (It.)

the three and five

"five past three"

b. ? le quattro meno cinquanta cinque

the four minus fifty five

"five past three"

(18) a. le quattro meno cinque (It.)

the four minus five

"five to four"

b. ? le tre e cinquanta cinque

the three and fifty five

"five to four"

However, there is a clear contrast in acceptability between the (a) and (b) counterparts in (17)-(18). In both cases, the relevant time-point, i.e. 3:05 in (17) and 3:55 in (18), is expressed in relation to the closest hour-time. We claim that this effect is due to a saliency condition, according to which closest hourtimes are more salient, and we will refer to these hour-times as Salient Reference Times, henceforth SRTs. In the following sections, we will show that a subset of SRTs give rise to a variety of aspectual construal in time-counting expressions.

Revista Letras,

Curitiba, UFPR, n. 96 , pp.377-397, jul./dez. 2017. ISSN 2236-0999 (versão eletrônica) 


\subsection{Time-counting expressions and relative view}

Natural languages articulate time in time-counting expressions in a prospective or retrospective point of view, as shown in the Romanian DPs in (19):

(19) a. Este doi și jumătate. (Ro.)

is two and half

"It is two thirty."

b. Este jumătate la trei.

is half to three

"It is two thirty."

The examples show that the same time-point can be referred to either under a prospective view, cf. (17a) and (19a) using an overt ADD operator e "and" in Italian and și "and" in Romanian, or under a retrospective view, see (19b); that is, rendering the time-point as a function of the time lacking for the following time-hour. These two types of view construal behave notably differently in Romance, regarding their linguistic properties. Prospective view is generally instantiated through an ADD operator feature, whereas in retrospective view construal, we can distinguish at least three types of contexts: i) those involving a [SUB] operator feature, see (20) with meno "minus" in Italian, ii) those showing a LOCATIVE/GOAL preposition, such as in (21) and (22):

le due meno cinque (It.)

the two minus five "five to two"

un quarto alle cinque (It.)

a quarter to-the five

"a quarter to five"

vinte para as cinco (Port.)

twenty for the five

"twenty to five"

And finally iii) partitive-like constructions, such as the Catalan one in (23): 
A. M. Di

SCIULlo \&

M. ESPAÑOL-

ECHEVARRÍA

Time-counting

expressions as aspectual complex numerals
(23)

$$
\begin{array}{lllll}
\text { un quart i cinc de } & \text { nou } & \text { (Cat.) } \\
\text { a quarter and five of } & \text { nine } & \\
\text { "twenty past eight" } & & & &
\end{array}
$$

In the following sections, we discuss the two latter contexts, which distinguish time-counting expressions from the rest of numerical expressions reviewed above in section 2 .

\subsection{Time-counting expressions and LOCATIVE/GOAL prepositional contexts}

Time-counting expressions of the LOCATIVE/GOAL subcase typically show a definite SRT preceded by a LOCATIVE/GOAL preposition, as shown in (21) repeated here under (24) for convenience:

$$
\begin{aligned}
& \text { un quarto alle cinque (It.) } \\
& \text { a quarter to-the five } \\
& \text { "a quarter to five" }
\end{aligned}
$$

In (24), the definite DP le ORE cinque "the HOURS five", cf. Kayne (2005), is preceded by the locative/goal preposition a "to". The SRT le cinque "five" is interpreted as a telic endpoint. The Portuguese example above in (22) also features a definite SRT preceded by a GOAL preposition para "to". This indicates that Italian and Portuguese pattern alike in this respect.

We analyze these time-counting expressions in terms of extended projections including Place and RelView categories, as discussed in Cinque (2010) for the syntax-semantics of locative/directional prepositions, (25):

$$
\begin{aligned}
& \text { a quarter }\left[_ { \text { Relview } } \text { quarterUP } \left[_ { \text { RelView } } \text { a quarter to } \left[_{\text {Place/ }}\right.\right.\right. \\
& \text { Goal } \\
& \text { "a quarter to five" }
\end{aligned}
$$

The measure phrase un quarto "a quarter" is internally merged to two successive RelView heads: an overt one a "to" and a covert one UP. The to-head places the measure phrase behind the SRT, interpreted as an endpoint. On the other hand, the UP-head maps the measure phrase onto a particular metrics, more explicitly, a series of decreasing number of quarters \{three quarters > two quarters > a quarter\} leading to the full-hour endpoint. There is a logical alternative to the UP-head, namely a DOWN-head, and we claim that this alternatively is instantiated in another Romance variety. According to Torres $\mathrm{i}$

Revista Letras,

Curitiba, UFPR, n. 96 , pp.377-397, jul./dez. 2017. ISSN 2236-0999 (versão eletrônica) 
Vilatarsana (2001), the time-counting expression in (26) is attested in a number of Valencian Catalan varieties:

$$
\begin{aligned}
& \text { tres quarts per les cinc } \\
& \text { three quarters for the five } \\
& \text { "a quarter to five" }
\end{aligned}
$$

The Italian example in (24) and the Valencian Catalan example in (26) denote the same time-point, i.e. 4:45. They also feature a definite SRT, i.e. le cinque/les cinc "five HOURS", preceded by a GOAL preposition a/per "to". However, the measure phrase is different, un quarto "a quarter" in Italian but tres quarts "three quarters" in Valencian Catalan. We claim that this difference in the measure phrase is the by-product of the polar head DOWN under RelView, as shown in the derivation in (27):

lencian Catalan (27)

$$
\begin{aligned}
& \text { three quarters }\left[_{\text {RelView }} \text { three quarters DOWN [ }{ }_{\text {RelView }}\right. \text { three } \\
& \text { quarters to }\left[_{\text {Place/Goal }}\right. \text { the five HOURS] three quarters]]]. }
\end{aligned}
$$

As opposed to UP in (25), DOWN in (27) maps the measure phrase tres quarts "three quarters" onto a series of increasing numbers of quarters \{a quarter $>$ two quarters $>$ three quarters $\}$. This explains why the same time-point, i.e. $4: 45$, is denoted by different measure phrases, one quarter vs. three quarters, under apparently the same conditions in (24) and (26) above, i.e. similar GOAL/ LOCATIVE prepositions and similar syntactic derivations.

\subsection{Time-counting expressions and genitive prepositional contexts}

In addition to time-counting expressions involving addition or subtraction operator features and those involving goal/locative prepositional projections, we distinguish a third type of time-counting expressions which lack the aspectual telic character of the latter ones, but also involve a prepositional configuration. The example in (28) illustrates a time-counting expression from standard Catalan:3

$$
\begin{array}{ll}
\text { un quart i cinc de nou } \\
\text { a quarter and five of nine } \\
\text { "twenty past eight" }
\end{array}
$$

3 This type of time-counting expression is also found in Southern German, cf. (i)-(ii):

(i) Es ist viertel neun (Uhr).

$$
\begin{aligned}
& \text { it is quarter nine (hours) } \\
& \text { "It is a quarter past eight." }
\end{aligned}
$$

(ii) Es ist fünf (Minuten) vor drei viertel drei (Uhr). "It is twenty to three." (minutes) before three quarters three (hours) 
A. M. Di

SCIULlo \&

M. ESPAÑOL-

ECHEVARRÍA

Time-counting

expressions as aspectual compleæa. numerals.

This type of time-counting expression involves a genitive preposition de "of" and a determinerless SRT, as shown by the ungrammaticality of (29a), as opposed to (29b):

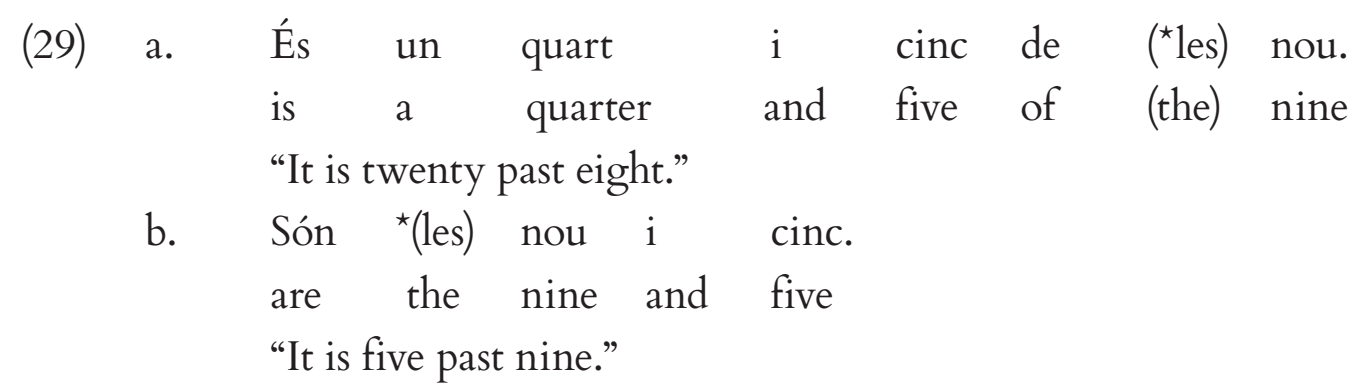

In addition, the SRT of the time-counting expression is not interpreted as a telic endpoint. Time-counting expressions involving addition or subtraction operators, as well as locative/goal prepositional projections, are contingent on the vicinity of an SRT, as shown in the examples (17)-(18) discussed in section 3.2. However, in the type of time-counting under consideration, the vicinity of an SRT does not play any role, as shown by the grammaticality of both (30) and (31):

Ca. (30)

tres quarts de nou

three quarters of nine

"eight forty five"

Ca.

un quart de nou

a quarter of nine

"a quarter past eight"

where (31) denotes the closest quarter to the ninth hour and (30) denotes the farthest one.

\subsection{Genitive time-counting expressions and partitives}

Genitive time-counting expressions share with partitives, in particular with pseudo-partitives a strong restriction on which $\mathrm{N}$ can occur in the sequence Num1 N of Num2, cf. dos quarts de nou "eight thirty", Num1 (dos "two") N (quarts "quarters") of (de) Num2 (nou "nine"). As shown in (32), only quarters can appear as $\mathrm{N}$ in genitive time-counting expressions in Catalan:

(32) a. un quart i cinc de nou (Ca.)
a quarter and five of nine
"twenty past eight"

Revista Letras,

Curitiba, UFPR, n. 96, pp.377-397, jul./dez. 2017. ISSN 2236-0999 (versão eletrônica) 

b. * vint (minuts) de nou
twenty minutes of nine
"twenty past eight"
c. * mitja (hora) de nou
half hour of nine
"eight and a half"

(32b, c) show that times internal to the hour cannot be denoted by using minutes or halves in genitive time-counting expressions, only quarters are allowed as shown in (32a). This restriction does not apply to other types of timecounting expressions. For instance, (33) shows that both quarters and minutes are equally compatible with an $[\mathrm{ADD}]$ operator feature:
Ca. (33) a. les nou i quart
the nine and quarter
"a quarter past nine"
b. les nou i deu
the nine and ten
"ten past nine"

The restriction illustrated in (32) is similar to the one observed in pseudopartitives, as shown in (34):

Ca. (34) a. un pessic de sal/ ${ }^{\star}$ arròs $/{ }^{\star}$ anys
b. un grapat d'arròs/anys
"a handful of rice/years"

In Catalan the atomizer noun pessic "pinch" is compatible with the mass noun sal "salt" but not with arròs "rice" or anys "years". On the other hand, the noun grapat "handful" is compatible with both arròs "rice" and anys "years". Thus, we claim that the N quart "quarter" in the relevant time-counting expressions is as an atomizer noun with respect to HOUR. However, as opposed to pseudo-partitives, we claim that the nominal expression following the genitive preposition de "of" is not an indefinite DP but rather a definite one, with a silent head noun HOUR and a Num(eral) raising to D, as in (35a):
Ca. (35) a. tres quarts de nou
three quarters of nine
"a quarter to nine"

$(=30)$ 
A. M. Di

SCIULlo \&

M. ESPAÑOL-

ECHEVARRÍA

Time-counting

expressions as aspectual complex numerals b.

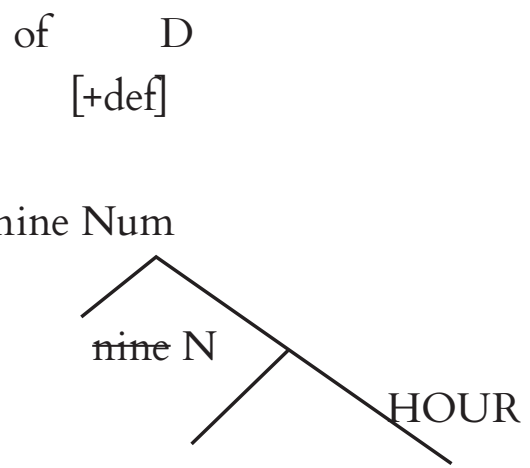

Comparative considerations in Romance suggest that there is such a Num-to-D movement, see Longobardi (2001) et seq.:
a. Il est trois heures (Fr.)
"It is three o'clock"
b. Sono le tre HOURS (It.)
"It is three o'clock"

In the French time-counting expression in (36a), the numeral trois "three" raises to D; this same D surfaces as definite determiner, le, in the Italian counterpart in (36b).

The derivation of genitive time-denoting expressions such as tres quarts de cinc "a quarter to five" could be derived on the basis of extended functional projections for prepositions including the higher measure phrase DegP, as in Cinque and Rizzi (2010), see (37b). This would lead to the derivation of telic and atelic time-counting expressions in a unique abstract space. We leave the investigation of this hypothesis for further research.
Ca. (37) a. tres quarts de nou (=30)
b. $\quad\left[\right.$ DegP three quarters $\left[_{\text {RelView }}\right.$ three quarters OUT $\left[_{\text {RelView }}\right.$ three quarters of [Place/Goal $[$ nine HOURS] three quarters]]]].

\subsection{Section summary}

Summarizing, time-counting expressions, like cardinal numerals, include functional heads that can be silent in some cases. We identified telic and atelic time construals, both mediated by prepositional structures. We provided a unified analysis of the variation between Romance languages in the expression of telic and atelic construals. The variation boils down to a minimal difference in the choice of a prepositional head in RelView. RelView, along with SRT are both aspectual categories contributing to the individuation of time points by means of time-counting expressions.

Revista Letras,

Curitiba, UFPR, n. 96, pp.377-397, jul./dez. 2017. ISSN 2236-0999 (versão eletrônica) 


\section{Consequences}

Our analysis has consequences for the understanding of Aspect in time at the syntax-semantic interface. Functional structure, including silent prepositions and PPs, provides further support to the phonetic-semantic interface asymmetry (CHOMSKY, 2008; DI SCIULLO, 2008) and to the syntax-semantic transparency hypothesis (CHIERCHIA, 2013; JACOBSON 2013). Timecounting expressions, like cardinal numerals, include directional prepositions that bring about the perspective in which numbers and time are identified in abstract space. Delimiting prepositions and PP structures are legible at the CI interface but not at the SM interface. The derivation of cardinal numerals and time-counting expressions in terms of Merge and Principles of efficient computation, minimizing externalization at the SM interface, and maximizing asymmetry at the CI interface (DI SCIULLO, 2015), brings further support to the Strong Minimalist thesis, according to which language is an optimal way to link sound and meaning.

\section{Overall summary}

We compared the syntactic and the semantic properties of cardinal numerals and time-counting expressions in order to identify their commonalities and their differences. Focusing on Romance languages, we argued that their

394 structure is derived by the same combinatorial operation, which may also generate unpronounced elements. We developed the hypothesis that they both include aspectual RelView categories, whereas only time-counting expressions include SRT. We analyzed timecounting expressions in terms of an extended prepositional projection for the syntax-semantics of prepositions, in order to formalize the spatial location of time. We provided derivations for additive and subtractive cardinal numerals as well as upward and downward oriented time-counting expressions. We derived the differences between closely related languages with respect to the prospective or the retrospective point of view from a minimal difference in the extended prepositional projection. By doing so, we proposed a unified account for the variety of Romance languages time-counting expressions. Finally, we identified consequences of our analysis for the Strong Minimalist Thesis, interface asymmetries and syntax-semantic transparency. 
A. M. Di

SCIUllo \&

M. EsPañol-

ECHEVARRÍA

Time-counting

expressions as aspectual complex numerals

\section{References}

CAMPS, M. Ni quarts ni hores. La Vanguardia 04/02/2013, 2013.

CANTOR, G. Uchenie o mnozhestvach Georga Cantora (Set theory by Georg Cantor). In: VASILIEV, A.V. (Ed.). Novye idei v matematike (New ideas in mathematics). v. 6, p. 90-184, 1914.

CHIERCHIA, G. Logic and Grammar. Oxford Studies in Semantics and Pragmatics. Oxford/New York: Oxford University Press, 2003.

CHOMSKY, N. Minimalist inquiries: the framework. In: MARTIN, R. et. al. (Eds.). Step by Step: Essays on Minimalism in Honor of Howard Lasnik. Cambridge, Mass.: MIT Press, 2000. P. 89-115.

CHOMSKY, N. Three factors in language design. Linguistic Inquiry, v. 36, p. 1-22, 2005.

CHOMSKY, N. The Biolinguistic Program: Where does it stand today? Ms. MIT, 2008.

CINQUE, G. Deriving Greenberg's Universal 20 and Its Exceptions. Linguistic Inquiry, v. 36, n. 3, p. 315-332, 2005.

CINQUE, G.; RIZZI, L. (Eds.). Mapping Spatial PPs: The Cartography of Syntactic Structures, v. 6. New York: Oxford University Press, 2010.

CORVER, N.; ZWARTS, J. Prepositional numerals. Lingua, v. 116, p. 811$835,2006$.

DIKKEN, M. den. On the functional structure of locative and directional PPs. In: CINQUE, G.; RIZZI, L. (Eds.). Mapping Spatial PPs: The Cartography of Syntactic Structures, v. 6. New York: Oxford University Press, 2010. p. 74126.

DI SCIULLO, A. M. Prefixed verbs and adjunct identification. In: DI SCIULLO, A. (Ed.). Projections and Interface Conditions: Essays on Modularity. New York: Oxford University Press, 1997. p. 52-74.

DI SCIULLO, A. M. Asymmetry in Morphology. Cambridge Mass.: MIT Press, 2005.

DI SCIULLO, A. M. Interface asymmetries. Canadian Journal of Linguistics, v. 53, n. 2/3, p. 139-142, 2008.

DI SCIULLO, A. M. Biolinguistics, minimalist grammars and the emergence of complex numerals. Evolang IX. Workshop on Theoretical Linguistics/ Biolinguistics, p. 13-18, 2012.

DI SCIULLO, A. M. On the domain specificity of the human language faculty and the effects of principles of computational efficiency: contrasting

Revista Letras,

Curitiba, UFPR, n. 96 , pp.377-397,

jul./dez. 2017. ISSN 2236-0999 (versão eletrônica) 
language and mathematics. Revista LinguiStica, v. 11, n. 1, p. 28-56, 2015.

DI SCIULLO, A. M. Aspect in Time. Talk presented at the Societas Linguistica Europea 49th Meeting, Naples, Italy, 2016.

DI SCIULLO, A. M.; TENNY, C. Modification, event structure, and the word/phrase asymmetry. In: TAMANJI, N.; KUSUMOTO, K. (Eds.). Proceedings of NELS 28, Amherst: GLSA, University of Massachusetts, p. 375-389, 1997.

GARCIA-PADRO, A. Decomposing the VP. Aspect, argument structure and the instrument-subject alternation. Talk presented at North Eastern Linguistic Society, Concordia University, 2015.

IONIN, T.; MATUSHANSKY, O. A healthy twelve patients. Paper presented at GURT, Georgetown University, Washington DC, 2004.

IONIN, T.; MATUSHANSKY, O. The composition of complex cardinals. Journal of Semantics, v. 23, p. 315-360, 2006.

JACKENDOFF, R. Semantics and Cognition. Cambridge, MA: MIT Press, 1983.

JAKOBSON, P. Direct Compositionality. In: WERNING, M.; HINZEN, W.; MACHERY, E. (Eds.). Compositional Semantics: An Introduction to the Syntax/Semantics Interface, Oxford Handbook of Compositionality. Oxford/ New York: Oxford University Press, 2013. p. 109-128.

KAYNE, R. Silent years, silent hours. Reprinted in KAYNE, R. Movement and Silence. Oxford/New York: Oxford University Press, 2005. p. 241-260.

KAYNE, R. A note on the syntax of numeric bases. In: SUZUKI, Y. (Ed.). In: Search of the Essence of Language Science: Festschrift for Professor Heizo Nakajima on the Occasion of his Sixtieth Birthday. Tokyo: Hituzi Syobo, 2006. p. 21-41.

KAYNE, R. The silence of heads. Ms. NYU, 2015.

KAYNE, R. Some thoughts on one and two and other numerals. Ms. NYU, 2016.

KOOPMAN, H. 2000. Prepositions, postpositions, circumpositions and particles: The structure of Dutch PPs. In: KOOPMAN, H. (Ed.). The Syntax of Specifiers and Heads, London: Routledge, 2010. p. 204-60.

LADUSAW, W. Semantic constraints on the English partitive constructions. Proceedings of WCCFL, v. 1, p. 231-291, 1982.

LONGOBARDI, G. The Structure of DPs: Some Principles, Parameters and Problems. In: BALTIN, M.; COLLINS, CH. (Ed.). The Handbook of Contemporary Syntactic Theory. Oxford: Blackwell, 2001. p. 562-603. 
A. M. Di

SCIULlo \&

M. ESPAÑOL-

ECHEVARRÍA

Time-counting

expressions as aspectual complex numerals

PARTEE, B.H.; BORSCHEV, V. Sortal, relational, and functional interpretations of nouns and Russian container constructions. Journal of Semantics, v. 29, n. 4, p. 445-486, 2012.

RAMCHAND, G. Verb Meaning and the Lexicon: A First-phase Syntax. Cambridge University Press, Cambridge, UK/New York, 2008.

RIEMSDIJK, H. van. Functional prepositions. In: PINKSTER, H.; GENEE, I. (Ed.). Unity and diversity. Paper presented to Simon C. Dik on his 60th birthday. Dordrecht: Foris, 1990. p. 229-241.

SCHWARSZCHILD, R. The role of dimensions in the syntax of noun phrases. Syntax, v. 9, n. 1, p. 67-110, 2006.

STAVROU, M.; TERZI, A. Types of numerical nouns. In: CHANG, C.; HAYNIE, H. (Eds.). Proceedings of WCCFL, v. 26, p. 429-437, 2008.

SVENONIUS, P. Spatial P in English, In: CINQUE, G.; RIZZI, L. (Eds.). Mapping Spatial PPs: The Cartography of Syntactic Structures, v. 6. New York: Oxford University Press, 2010. p. 127-160.

TENNY, C. Grammaticalizing Aspect and Affectedness. PhD. Dissertation, MIT, 1987.

TERZI, A. Locative prepositions and place. In: CINQUE, G.; RIZZI, L. (Eds.). Mapping Spatial PPs: The Cartography of Syntactic Structures, v. 6. New York: Oxford University Press. 2010. p. 196-224.

TORRES I VILATARSANA, M. L'expressió de les hores en català: anàlisi contrastiva. Caplletra, v. 30, p. 169-198, 2001.

TORTORA, C. Aspect inside PLACE PPs. In: ASBURY, A.; DOTLAČIL, J.; GEHRKE, B.; NOUWEN, R. (Eds.). Syntax and Semantics of Spatial P. Amsterdam: John Benjamins, 2008. p. 273-301.

TRAVIS, L. Event structure in syntax. In: TENNY, C.; PUSTEJOVSKY, J. (Eds.). Events as grammatical objects: The converging perspectives of lexical semantics and syntax. Stanford, CA: CSLI Publications, 2000. p. 145-185.

ZABBAL, Y. The syntax of numeral expressions. Ms. University of Massachusetts, Amherst, 2005.

Submetido em: 15-03-2017

Aceito em:25-04-2017

Revista Letras,

Curitiba, UFPR, n. 96 , pp.377-397,

jul./dez. 2017. ISSN 2236-0999 (versão eletrônica) 